\title{
Nursing consultations to children in primary health care: a feedback of researched data
}

\author{
Consulta de enfermagem à criança na atenção primária à saúde: uma devolutiva de dados pesquisados \\ Consulta de enfermería al niño en la atención primaria de salud: una devolutiva de datos investigados
}

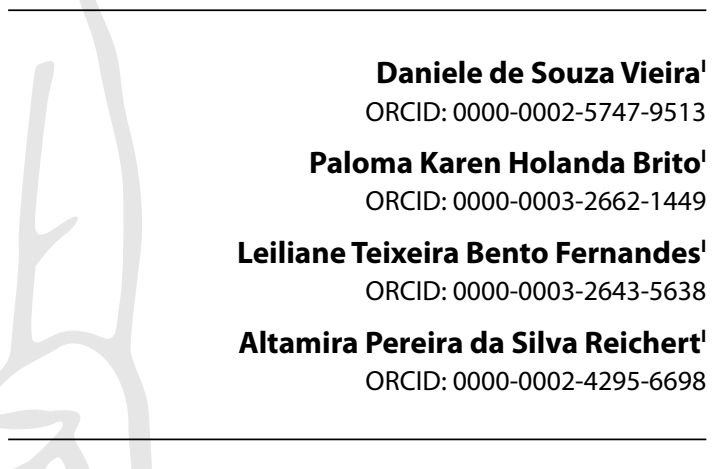

IUniversidade Federal da Paraíba. João Pessoa, Paraíba, Brazil.

How to cite this article:

Vieira DS, Brito PKH, Fernandes LTB, Reichert APS. Nursing consultations to children in primary health care: a feedback of researched data. Rev Bras Enferm. 2021;74(Suppl 4):e20200090. https://doi.org/10.1590/0034-7167-2020-0090

\section{Corresponding author: \\ Daniele de Souza Vieira}

E-mail: daniele.vieira2015@gmail.com

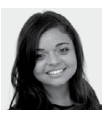

EDITOR IN CHIEF: Antonio José de Almeida Filho ASSOCIATE EDITOR: Alexandre Balsanelli

Submission: 07-01-2020

Approval: 09-25-2020

\begin{abstract}
Objective: To report the results of a dissertation developed with nurses who perform childcare consultations in Family Health Units in a Health District of João Pessoa, Paraíba, Brazil. Methods: Experience report of the presentation and interpretation of the research results, in 2018, with 42 nurses, using the conversation strategy with two focus groups. Results: The nurses showed disappointment with the negative results evidenced in the study's feedback, but they highlighted the importance of this moment for discussion and reflection of their practices, thus arousing the interest in qualifying the child's health care. Final considerations: This study achieved the objective of promoting the dissemination of the findings of a research, coupled with the social and ethical commitment to return to the nurses and participating services with the feedback of the research results to improve the reality in which they work.

Descriptors: Office Nursing; Child; Primary Health Care; Growth and Development; Child Care
\end{abstract}

\section{RESUMO}

Objetivo: Relatar a devolutiva dos resultados de uma dissertação desenvolvida com enfermeiros que realizam consultas de puericultura em Unidades de Saúde da Família de um Distrito Sanitário de João Pessoa, Paraíba, Brasil. Métodos: Relato de experiência da apresentação e interpretação dos resultados da pesquisa, no ano de 2018, com 42 enfermeiros, utilizando a estratégia de roda de conversa com dois grupos focais. Resultados: Os enfermeiros demonstraram desapontamento com os resultados negativos evidenciados na devolutiva do estudo, mas destacaram a importância desse momento para discussão e reflexão de suas práticas, despertando, assim, o interesse para qualificação da atenção à saúde da criança. Considerações finais: Este estudo alcançou o objetivo de promover a divulgação dos achados de uma pesquisa, aliado ao compromisso social e ético de devolver aos enfermeiros e serviço participantes a devolutiva dos resultados da pesquisa para melhoria da realidade em que atuam. Descritores: Consulta de Enfermagem; Criança; Atenção Primária à Saúde; Crescimento e Desenvolvimento; Cuidado da Criança.

\section{RESUMEN}

Objetivo: Relatar devolutiva de los resultados de tesis desarrollada con enfermeros que realizan consultas de puericultura en Unidades de Salud de la Familia del Distrito Sanitario de João Pessoa, Paraíba, Brasil. Métodos: Relato de experiencia de la presentación e interpretación de los resultados de la investigación, en 2018, con 42 enfermeros, utilizando la estrategia de rueda de charla con dos grupos focales. Resultados: Enfermeros demostraron decepción con los resultados negativos evidenciados en la devolutiva del estudio, pero destacaron la importancia de eso momento para discusión y reflexión de sus prácticas, despertando, así, el interés para calificación de la atención de salud del niño. Consideraciones finales: Este estudio alcanzó el objetivo de promover la divulgación de los hallados de una investigación, aliado al compromiso social y ético de desarrollar a los enfermeros y servicio participantes la devolutiva de los resultados de la investigación para mejoría de la realidad en que actúan. Descriptores: Consulta de Enfermería; Niño; Atención Primaria de Salud; Crecimiento y Desarrollo; Cuidado del Niño. 


\section{INTRODUCTION}

Nurses in Primary Health Care (PHC) have in their work process the function of monitoring the growth and development of children assigned to their territory through the implementation of childcare consultations, in order to intervene in the promotion, prevention, treatment and restoration of the health of these individuals ${ }^{(1)}$. This strategy, which provides comprehensive and longitudinal attention to the health of children and their families, has great potential to reduce health problems and child morbidity and mortality.

In this context, a master's dissertation was developed in 2017 in order to analyze the care actions performed by nurses during childcare consultations at Family Health Units (FHU) in the city of João Pessoa, Paraíba. As a result, it was found that, among nurses' practices, actions aimed at regulating the vaccination calendar and iron and vitamin A supplements were more effective, as well as growth measures and records in the child health records. On the other hand, weaknesses were found in the dimensions related to anamnesis, physical examination, developmental assessment, health education and acceptance of the mother-child binomial ${ }^{(2)}$.

In view of this reality, it should be noted that the results from quality scientific studies must go beyond disclosure to the academic community. They must reach the participants ${ }^{(3)}$, who are more than the data sources and are characterized as actors with the potential of transforming the reality studied.

Therefore, feedback in the research processes enables and affirms the participation of everyone involved in the research, also being considered a step in the inclusion of dialogic activities with mutual and ethical participation ${ }^{(4)}$.

Presenting the results of the study to the participants or services studied is part of the current documentation for conducting research with human being $s^{(5)}$. It is expected that these investigations in communities, whenever possible, will continue to have their results perceived after their conclusion. Furthermore, it is expected that, when there is a real benefit in encouraging changes in customs or behaviors, communication with people, communities, and competent authorities will be included whenever possible, whether in terms of social feedback or in terms of access to procedures, products or research agents.

In this sense, Palmeira et al., $2019^{(3)}$ highlights that, when reviewing the literature on the feedback of the result of researches and experiences in the LILACS, MEDLINE and BDEnf databases, significant gaps were noticed in academic publications that explained how the researchers discussed the results produced after conducting the studies. Only two articles were found, both from between 2013 and 2016. Therefore, it is in this context, that of the researcher's commitment, that this experience report is justified.

\section{OBJECTIVE}

To analyze the feedback of the results of a dissertation developed with nurses who perform childcare consultations in Family Health Units in a Health District of João Pessoa, Paraíba, Brazil.

\section{METHODS}

\section{Ethical aspects}

This study is linked to a bigger project entitled "Child development surveillance: paths and perspectives for Nursing", which was approved by the Ethics and Research Committee of the Health Sciences Center at the Federal University of Paraíba. The formal requirements contained in the rules of Resolution $466 / 12$ of the National Health Council ${ }^{(5)}$ were met. All participants signed the Free and Informed Consent Form (FICF) when they attended the place of the feedback.

\section{Type of study}

This is an account of the experience of publishing the results of a master's dissertation entitled "Childcare consultation: a look at the nurse's practice, for nurses working in Family Health Teams"(2).

\section{Study scenario}

The research was carried out in the city of João Pessoa, Paraíba, which presents the decentralized Primary Care network, demarcated by five Health Districts (SD). However, to carry out the study, one of the five was drawn as the research setting. It had 49 Family Health Teams (EqSF). For the experience of giving feedback about the findings, the meeting room of the district's headquarters was chosen, which had an appropriate structure to accommodate the nurses, having didactic resources such as a computer and a projector for the presentation of the research results.

\section{Methodological procedures}

Since the objective of the research was showing its results to all nurses from the DS EqSFs, whether they participated in the initial data collection, that is, in the dissertation, or not, there was an attempt to enable the visualization of the work beyond the walls of the higher education institution (HEI) and to bring together professionals in the scientific literature, since, sometimes, the time required by the work demands prevents the updating of the scientific knowledge of these professionals.

To make this moment feasible, the DS technical team was contacted to articulate the presentation of the feedback of the research results to the nurses. After the acceptance of the proposal by the direction of the Health District, it took the responsibility for inviting the 49 nurses to the meeting. It is worth noting that the meetings with nurses took place at different times, meaning that two groups were formed, since the dynamics of the service did not allow everyone to leave the health units at the same time. These meetings took place in the afternoon, considering that, in general, the demands for care at the USFs are greater in the morning shift.

\section{Data collection and organization}

The data collection was carried out through a focus group (FG) in August 2018. The FG is a group interview that allows the deepening of a research topic through consensus and/or disagreements between the individuals that compose it. This 
technique provides the interaction between the subjects and allows the researchers to discover the different interpretations of the interviewees ${ }^{(6)}$. The moderator was the researcher who developed the master's dissertation, and the observers, two nursing students and members of the Study Group on Child and Adolescent Health in Primary Care (GESCAAP), at the Federal University of Paraíba.

Participants were chosen according to the criterion of representativeness. This criterion considers "which social individuals have a more significant link to the problem to be investigated [...] the good sample is one that makes it possible to cover the whole of the problem investigated in multiple dimensions"(6). From the 49 nurses invited, 42 agreed to participate: 24 from GF-1 and 18 from GF-2. It should be noted that some representatives of the DS technical team were also listening. At each meeting, the individuals were distributed in the room in a circle, to encourage interaction and eye contact between them.

After the presentation of the main results of the study, through a projection, a conversation was initiated with participants in a circle. The triggers for the FGs were: What could you say about the results presented? What is your vision and opinion regarding the reality you are experiencing? Two recorders were used, and the meetings lasted from 60 to 75 minutes. It should be noted that a field diary was used to record the perceptions about the group, related to attitudes, behaviors, and main notes during the discussions.

To identify nurses, the term "Nurse" was used, and a number was added to differentiate between them; in addition, the groups were named $\mathrm{G} 1$ and $\mathrm{G} 2$, according to their order of participation.

\section{RESULTS}

The meetings were attended by nurses and some representatives of the DS technical team. Initially, at each meeting, there was a presentation by the team, the moderator, and the observers, as well as the other participants, as there were new professionals working in the service.

Then, it was stated that the group discussion would be recorded, to analyze the subjective data of that moment. The informed consent form was also given to those who participated in this new phase of the research.

During the presentation, the participants were attentive to the quantitative results of the study and to the reflections they provided in their practice. Then, the guiding questions were asked, and nurses were encouraged to comment on the research findings and evaluate the data, highlighting the following theme.

\section{Rethinking the practice after research}

Through a reflective dialog, participants perceived the importance of feedback from research to encourage the rethinking of professional practices, since nurses are often accommodated in their actions and do not have time and encouragement for these reflections in their daily lives.

I mean... this job is very good so everyone has a deeper look. We let it become a routine. Sometimes, when we wake up [the participant snapped their fingers] we have a new point of view and try to provide better childcare because we know that everyone here already do good childcare, let's try and improve, and each one will give their best. (Nurse. 02 - G2).

Really, they [the results] must be taken into account, with regard to the reflection, so we rethink our own professional practice in some aspects that I wasn't aware needed to be considered, and I'm not doing them or I'm doing them in an insufficient way, so I can try to improve, right? (Nurse. 05 - G2)

I really liked your work. It may be that we start to accommodate to certain routine actions. We must get up and continue studying; [in the field of] health, we have to continue studying always, daily, everyday it changes... It is always good to have an outside look about how is assistance taking place in our work, including to improve a little every day. (Nurse. 06 - G2)

During the presentation of the results, it could be noted that some nurses felt embarrassed and did not want to talk about the subject, while others stated that, at first, they felt that the research team was judging them, while also feeling let down by the results of the research. this took place because $96.77 \%$ of the participants of the research team were found to have a performance that varied from low to medium, according to the calculation of the General Index (GI). This data shows that the quality of the actions is below the acceptable level, which would include a Gl above $75 \%{ }^{(2)}$.

This index was a result of the mean between the score found in the three consultations from each professional, according to the dimensions of care implemented in childcare consultations, in accordance to the criteria established in the data collection instrument elaborated based on the directives of child health. However, when this data was provided, the researcher made a point to assure participants that the feedback did not aim to blame them in any way, but to make them reflect on their practices, free of prejudgments. This contributed to diminish their resistance, as they opened up to the possibility of improving their actions in childcare.

Your research was really good, wonderful, but unfortunately your conclusion was that of a low deficit [in the performance of childcare]... I hope this research of yours can be a push forward for the conjuncture to actually change, because it's easy to criticize, but there's an entire structure, if you don't go after it, don't sit, don't teach yourself, you know? (Nurse. 10-G1)

Your research is beautiful, wonderful, but you'll never see not even $80 \%$ of what you're doing there, because this depends on change, on the change of the things in how they are seen and how you consider them. (Nurse. $12-\mathrm{G} 1$ )

After you spoke, explained that you were not criticizing, I started to try and open my mind, to try and understand better what was being presented... to say that the performance was not satisfactory impacts us to a point, right? But when you said that we are never $100 \%$, really, that is what made my mind open even more. And so I notice that I may be satisfactory in certain points but not in others, that this is part of being human, you know? That is why I confess that I'm seeing your research with a different look at the end. (Nurse. $05-\mathrm{G} 2$ ) 
By noticing this problem, there was an attempt to clarify, for the nurses, the many factors that can compromise the professional practice. That includes working conditions, overload of attributions, lack of supplies, lack of opportunities for training, lack of adherence from the mothers in childcare, among others. Additionally, the feedback made it possible to confirm and verify the data obtained in the previous stage of the study, in addition to making it possible to show that not all researches have satisfactory research, despite the fact they are important to point out what the reality is and propose changes that aim to transform the practice, according to the needs of the service.

In this context, the statements highlight that this moment was valued by the nurses, since this initiative was a novelty for them, who reported not receiving feedback from the researches in which they participate.

\begin{abstract}
Imyself, since Istarted [working], I never participated in any research from which I received a feedback about what was researched. And also, in addition to the feedback, you didn't think only on your project, only on your [master's] degree. You are thinking about changing what you saw here. Props for that! (Nurse. 01 - G1)
\end{abstract}

I participated in many researches, and many researchers did only the research, there was no feedback. And you're giving us feedback, and l love it. You can count on me for the next one. (Nurse. 02 - G1)

The research itself, (just) for researching, is already important. [Even more] important is when you research and show the results. And researching is this that you're doing. (Nurse. $03-\mathrm{G} 1$ )

Furthermore, it was gratifying to find that giving a feedback on the results of the research made it possible to awaken the nurses for the need of further qualification in childcare, and to seek knowledge autonomously. The management of the DS was also considered to be co-responsible, for the planning of formalized education strategies.

What led to this deficit today, after 18 years or more, was because the Family Health has been in João Pessoa for 20 years and there has never been training, so that's it... There's training about hypertension, diabetes, leprosy, tuberculosis, but childcare, no. (Nurse. 10-G1)

But, in practice, what we see corroborate the reflections of the research [related actions are seldom implemented], and the vaccine situation was high because training about vaccines, the training always has these. Whenever there is a new vaccine [...] we train over and over, always updating more than once a year. Because it's what we see the most with regard to children. (Nurse. 13-G1)

We should and must put our heads down a bit and reflect on this issue of refreshing knowledge. The service has really not been offering, we have been making a lot of effort to try and learn. (Nurse. 14-G1)

Not to mention that the training, we must have it, we must read, we, each professional must search, must seek their own knowledge and professional growth. But we need the manager, the employer to collaborate, right? (Nurse. 01 - G2)
So, if the management can collaborate with us and provide more training courses so we can improve more and more, I believe we as nurses can improve this data. (Nurse. 02 - G2)

It can be noted that the deficit in the training can lead to inability in the provision of health care, since unprepared professionals cannot act in a resolutive way with regard to the health problems of users. Therefore, as a way to help nurses and, consequently, improve the assistance offered to the children, the researchers suggested an educational intervention about surveilling the growth and development in childcare consultations. This pleased the participants, who considered the possibility of reevaluating their practices.

You said what the shortcomings were and you'll try in the next to improve the ones you found. This is a very positive study of a kind we've never seen. Conclude the next step, which is the training with us, because everyone is lacking in this area. (Nurse. $01-\mathrm{G} 1$ )

You researched and gave the support for us to change this, for this situation to be changed. Thank God you'll come back, we'll have another opportunity. That is great! Everything was constructive criticism. I accept all criticism that is constructed. It would mean nothing if you arrived here and criticized and gave us no conditions to say: "Let's try to change that, to change this situation." So, about this, you really deserve props. (Nurse. 02 - G1)

You'll have to reevaluate, after the training, if your indexes will improve [...] You'll need to open the space for a reconstruction. (Nurse. $01-G 2$ )

Finally, although at first nurses had not received the feedback well, it became clear that, when the meetings were finished, the initiative was valued and they were satisfied, to the point of asking for a new evaluation of their practices after the training suggested. That shows the positive result attributed to the scientific production and its feedback to the participants. It stands out that this occasion was important both for the participants and for the researchers, since it made it possible to understand the meaning the participants attributed to the action of giving feedback on the results of the study.

\section{DISCUSSION}

The participants of this study were individuals who had been working in their respective services for time enough to know their territory and develop actions that are compatible to the reality of their clients. However, the results of the earlier research carried out with most of them showed a deficit in the implementation of the many dimensions of care, which must be included in the childcare consultations according to the national directives of attention to children's health. Therefore, this impairs the provision of integral assistance to these individuals and families, especially considering that only one nurse among the 31 participants in the study had an acceptable performance, according to the $I G^{(2)}$.

Therefore, it became evident that the dialog that took place in this experience of giving a feedback of the results led them to rethink their professional practices. The dialog, as an educational practice, enables both an understanding of the knowledge the professional 
has about a certain subject, and the transformation and resignification of this knowledge, making new actions viable as a response ${ }^{(7)}$.

One of the realities shown in the experience of the feedback corroborates a study that showed the difficulties of nurses in accessing the results of researches, as well as the distance between the scientific production and its implementation in nursing practice, which is directly related to the needs for knowledge resulting from the demands of health care provision ${ }^{(8)}$.

Therefore, the moment of the feedback is valued, considering that it offers clarifications about the results and allows for a discussion about it between participants and researchers, which would be impossible if the literature of scientific works originating from the research was the only source consulted. Therefore, the relevance of offering feedback on the research in the scope of work is reiterated, so that the meaning of the findings by the nurses can be found ${ }^{(8)}$.

Furthermore, the feedbacks have changed the scope of researches with regard to transition. They go from simple data collections to processes of researching with movements related to raising questions, two-way constructions, in which the researcher and the subject of the research (re)create one another ${ }^{(4)}$.

Another issue highlighted by the nurses during the feedback was the lack of training courses, a finding that was similar to that of another study ${ }^{(9)}$, carried out with nurses who work in Primary Health Care Units, a study which found the same shortcoming in the process of continued and permanent education. This is worrisome, because the deficiency in the training of the Primary Health Care Professionals has negative repercussions in the quality of care and interferes in the follow up process of children ${ }^{(10)}$.

However, in the reflections generated by the feedback, it is noteworthy that, although management is responsible for offering professional training activities ${ }^{(9)}$, nurses report to be aware that they too must seek professional improvement, through searches in literature and the exchange of experiences with their peers.

Therefore, the proposal from the researchers, of offering training sessions about monitoring children's growth and development, which was based on the demands of the participants, was well-received by the management of the DS and by its target audience, who also proposed a reevaluation of their practices after the intervention. This initiative is reinforced by the literature as it clarifies that, after a training intervention with nurses, they present positive results with regard to transformations in their professional practice and to developing a broader look towards children's health ${ }^{(10)}$.

\section{Study limitations}

A limitation of this study is the fact that it was not possible to show the voice of some nurses present in the focal groups directly, since they did not feel comfortable to express their opinions in front of DS coordinators. Furthermore, it was difficult to find scientific literature to serve as a base for the discussions on the theme in many realities.

\section{Contributions to the Field of Nursing}

The feedback of findings from studies is right prescribed by the resolution of the Research Ethics Committee ${ }^{(5)}$. However, it is seldom implemented in health care researches involving human beings, which is made clear by the lack of publications of the type. Therefore, this study can be a model for similar strategies to be used more and more. After all, they can bring benefits to the public who is participating and tend to lead researchers to reflect on the outcome of their researchers, improving health assistance and getting the university closer to the community.

\section{FINAL CONSIDERATIONS}

This study reached the objective of disseminating the findings of a research, allied to the social and ethical commitment of offering a feedback to the professionals and services who are participating, so they can improve health care in their work processes.

Therefore, the debate on the results of the study led to a reflection with the participants about the work in the health field, in addition to the sharing of different points of view between nurses. It especially reiterated the need for training sessions about the monitoring of children's growth and development, to promote an integral health care.

Considering the need to attend to the commitments agreed upon, a research to train these nurses is already being developed. The training proposed aims to improve their theoreticalscientific knowledge about the monitoring of children's growth and development.

Finally, it can be noted that the feedback was essential for nurses to take a critical and reflective ownership of their own reality, rethinking actions that transformed the weaknesses in possibilities for changing the health care to children.

\section{REFERENCES}

1. Ferreira FA, Freitas RSC, Santos MCS, Silva SRM, Silva AM, Santos MKS. Puericulture consultation: problems found in those under 2 years old. Rev Enferm UFPE. 2019;13:e240072. https://doi.org/10.5205/1981-8963.2019.240072

2. Vieira DS. Consulta de puericultura: um olhar sobre a prática do enfermeiro. [Dissertação] [Internet]. 2017 [cited 2020 May 19]. Repositório Institucional da UFPB. Available from: https://repositorio.ufpb.br/jspui/handle/tede/9449

3. Palmeira IP, Rodrigues ILA, Teixeira E, Panarra BACS, Almeida AIS, Carneiro DF, et al. Feedback on research results to healthcare professionals in the context of HIV. Rev Bras Enferm. 2019;72(5):1416-20. https://doi.org/10.1590/0034-7167-2017-0875

4. Ferreira JP, Silva CO, Barros MAB, Rotenberg L. Afirmando um éthos de pesquisador em saúde: processos participativos de restituição de resultados de pesquisas. Trab Educ Saúde. 2018;16(3):919-33. https://doi.org/10.1590/1981-7746-sol00081 
5. Ministério da Saúde (BR). Conselho Nacional de Saúde (CNS). Resolução n 466, de 12 de dezembro de 2012. Aprova as diretrizes e normas regulamentadoras de pesquisas envolvendo seres humanos [Internet]. 2012 [cited 2019 Dec 13]. Available from: https://conselho.saude. gov.br/resolucoes/2012/Reso466.pdf

6. Minayo MCS (Org.). O desafio do conhecimento: pesquisa qualitativa em saúde. São Paulo: Hucitec; 2014.

7. Maeyama MA, Cutolo LRA, Chaves MV, Barni RS. Projeto Sérgio Arouca: relato de experiência. Rev Bras Educ Méd. 2018;42(1):45-54. https:// doi.org/10.1590/1981-52712015v40n1e02312014

8. Silva IR, Leite JL, Trevizan MA, Silva TP, José SAP. Connections between research and health care assistance: emerging challenges for science, innovation and technology in nursing. Texto Contexto Enferm. 2017;26(4):e2470016. https://doi.org/10.1590/0104-07072017002470016

9. Melo FMS, Oliveira BSB, Oliveira RKL, Bezerra JC, Silva MJN, Joventino ES. Nurses'knowledge about work accidents. Rev Rene. 2017;18(2):173-80. https://doi.org/10.15253/2175-6783.2017000200005

10. Reichert APS, Nóbrega VM, Damasceno SS, Collet N, Eickmann SH, Lima MC. Surveillance of child development: practices of nurses after training. Rev Eletrôn Enferm. 2015;17(1):117-23. https://doi.org/10.5216/ree.v17i1.27722 